\title{
Australian Infrastructure Financial Management Guidelines
}

\section{Commonwealth Journal of Local Governance}

Issue 4: November 2009

http://epress.lib.uts.edu.au/ojs/index.php/cjlg

\section{Chris Champion}

Institute of Public Works Engineering Australia

\section{Introduction}

The Institute of Public Works Engineering Australia (IPWEA) has recently published the Australian Infrastructure Financial Management Guidelines. The Guidelines provide new assistance to link the technical (engineering) and financial aspects of managing infrastructure and services, and to assist infrastructure owners such as local government to develop sustainable long-term asset and financial management plans.

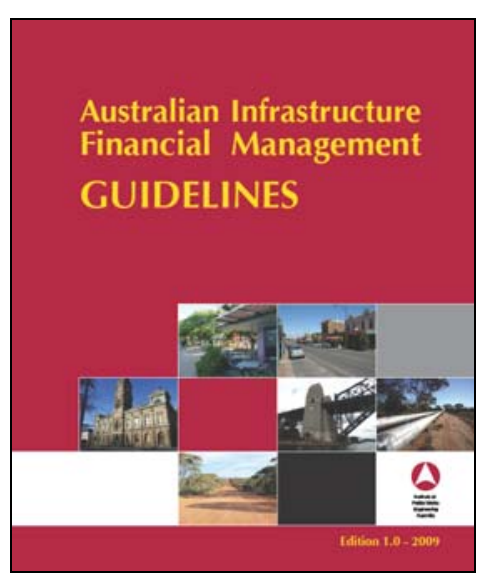

Financial management for long-life infrastructure assets (such as roads, water, sewerage, and stormwater networks, and community buildings) is about ensuring sustainability in the provision of services required by the community. These new Guidelines offer advice for every organisation and individual with responsibility for the management of infrastructure assets. They assist in defining best practice approaches for:

- Accounting for infrastructure

- Depreciation, valuation, useful life, fair value

- Managing financial sustainability

- Integrating asset management planning and long term financial planning

- Meeting requirements for financial reporting 
The project was a joint initiative of IPWEA and the National Local Government Financial Management Forum. ${ }^{1}$ A steering committee representing national and state governments, technical and financial professionals, local government associations and auditors oversaw it.

\section{Background}

Several infrastructure and financial sustainability studies have been published in Australia over the last few years. These studies identified deficiencies in service planning, asset management planning, long-term financial planning and financial reporting. An overview report prepared for the Australian Local Government Association (PwC, 2006, p. 6), concluded that around 35\% of Australian councils are not financially sustainable. Also, the national infrastructure renewal backlog was estimated at \$14.6bn. The additional funding required to clear this backlog and cover underspends on renewals is estimated at $\$ 3.1 \mathrm{~m}$ per council per annum or $\$ 2.16 \mathrm{bn}$ nationally (PwC, 2006, Table E2, p. 11).

This \$2.16bn funding shortfall represents around 9\% of local government's \$23.08bn 2005/06 income base and around 24\% of local government's rate income of \$8.92bn (DoTaRS, 2007, Table 1.5, p 14).

The Australian Local Government Association (ALGA) report observed that local government is responding to ever rising community expectations by providing a growing range of services and infrastructure. Rising costs exceeding revenue growth are seeing a significant number of councils develop financial operating deficits. A common response to 'balance the budget' is to defer or reduce expenditure on the renewal of community infrastructure. The ALGA report concludes that major reforms are required in the way local government is funded and the way it operates. It states that in the absence of major reforms, Australian local governments will have to cut back on services, reduce their asset base or obtain additional revenue if they are to be sustainable in the longer term.

\footnotetext{
${ }^{1}$ The authors were John Howard, Jeff Roorda \& Associates; Jim Dixon, GAAP Consulting; and John Comrie, JAC Comrie Pty Ltd. The writing team brought together skills and experience in infrastructure asset management, financial management, and accounting and audit.
} 
Part of the reason for the sustainability of infrastructure being questioned, is the lack of nationally consistent data on the condition of infrastructure, the quality of services provided from infrastructure, and the costs involved in providing those services. Uniting the technical and financial aspects of infrastructure asset planning and financial planning and management will increase the quality of data used for financial reporting and quality of decisions made on service delivery from existing and new assets.

\section{National Action}

Australian Prime Minister Kevin Rudd stated one of the three purposes of the inaugural Australian Council of Local Government meeting held on 18 November 2008 was to "begin work on a planning reform to improve infrastructure and services delivery across Australia”. His address to the meeting further set the national agenda for asset and financial management:

We must improve asset management and financial management. We need to know what we've got, what condition it is, whether it needs to be repaired and how much it costs to maintain. (ACLG, 2008)

The Local Government and Planning Minister’s Council (LGPMC) (2009) has adopted three nationally consistent frameworks for:

1. Assessing local government financial sustainability

2. Asset planning and management

3. Financial planning and reporting.

The LGMPC (2009) has set a target for substantial implementation of these national frameworks by 31 December 2010. The Australian Infrastructure Financial Management Guidelines are a contribution to the achievement of that objective.

\section{Guidelines: Structure And Content}

The guidelines are set out in 4 parts.

- Part A: Introduction introduces the guidelines and provides background including reasons for their development.

- Part B: Planning discusses the planning phase of infrastructure financial management, namely service planning, asset management and long term financial planning. 
- Part C: Financial Reporting describes the regulatory framework covering financial reporting and auditing of financial reports.

- Part D: Application covers the practical application of the above parts to valuation, accounting for infrastructure, financial reporting and planning, administration and implementation.

The guidelines are designed to cover the needs of both 'core' (those beginning the process) and 'advanced' users. The movement from 'core' to 'advanced' is one of continuous improvement in priority areas. A Quick Guide is included to provide information on the key points of the guidelines.

\section{Financial Sustainability Indicators}

An organisation is seen to be sustainable if its infrastructure and financial capital can be maintained over the long-term. The guidelines propose eight nationally consistent financial sustainability indicators: operating surplus; operating surplus ratio; net financial liabilities; net financial liabilities ratio; interest cover ratio; asset sustainability ratio; asset consumption ratio; and asset renewal funding ratio.

\section{Accounting for Property, Plant and Equipment}

The Australian Accounting Standard AASB 116 Property, Plant and Equipment prescribes the accounting standard for property, plant and equipment assets so users of financial reports can discern information about the entity's investments in its assets. Property, plant and equipment are tangible assets that:

- $\quad$ are held for use in the production or supply of goods or services, for rental to others, or for administrative purposes, and

- $\quad$ are expected to be used during more than one (financial reporting) period.

\section{Accounting for Infrastructure}

The key accounting requirements for infrastructure assets can be illustrated by three essential steps:

1. Recognition: the asset is identified at component level

2. Measurement after recognition: the asset is revalued at 'fair value' option 
3. Reporting asset consumption - a depreciable amount of an asset is to be allocated over asset's useful life in a manner reflecting the pattern of consumption of future economic benefits.

\section{Reporting Asset Values and Consumption}

Depreciation is the financial representation of the consumption of an asset in the reporting period. The guidelines propose an eleven-step valuation methodology:

1. Define valuation component level

2. Develop asset registers into database of components

3. Develop standard replacement costs

4. Assess residual value

5. Assess useful lives

6. Assess remaining useful life

7. Determine depreciation method

8. Calculate accumulated depreciation, fair value and depreciation

9. Test for impairment and calculate impairment loss

10. Sum component values

11. Assess land value where applicable.

The future economic benefits (FEB) for infrastructure assets is the entity's ability to provide services to its customers/community in the future. The recommended methodology for ensuring that the depreciation method reflects the pattern of consumption of FEB is:

1. Define services provided

2. Identify measure of consumption of services

3. Identify pattern of consumption

4. Select depreciation method.

Good Financial Management - The Key to Overcoming Asset Management Funding Gaps

Assets should be managed to provide the required level of service at the optimal life cycle cost, and financial reports should reflect how the assets are performing in providing the required level of service. The asset manager's role is to ensure assets are managed, maintained, rehabilitated and replaced at points in time, and in ways that achieve 
required service standards and minimise whole of life costs. Unfortunately, all too often in infrastructure-intensive entities this objective is not being achieved. As a result whole of life costs are higher and service levels are lower than necessary.

The problem typically arises because:

- budgets and service level decisions are made based on short term cash costs and cash availability

- in acquiring new assets to deliver higher and additional services, not enough thought is given as to whether the entity will have the capacity to fund increasing maintenance as existing and proposed additional assets age.

As a consequence, assets prematurely fail. Their economic life is not realised and whole of life costs are therefore higher. The entity is often not in a position to fund the assets' rehabilitation or renewal and unwilling to raise additional borrowings to do so, and as a result, service standards fall. In order to make sound asset management decisions, it is essential to:

- have reliable forecasts regarding likely future asset performance and associated costs

- have an appreciation of future revenue raising capability and affordability of service level proposals

- be willing to utilise additional debt where required and cost effective to do so.

Thus, sustainable asset management requires effective long-term financial planning.

\section{Operating Sustainably}

Generally speaking, and in the absence of other over-riding objectives or directions, public sector business entities should strive to generate operating revenue approximately equal to their operating expenses calculated on an accrual accounting basis. A break-even operating result for local governments would mean that the property rates and other charges people are paying is equivalent to the costs incurred by an entity in providing its existing levels of service. (Note that a small operating surplus may also be appropriate having regard to risk and uncertainty and inter-generational equity considerations.) 
The decision to add to the stock of assets will add to operating costs in future years through increased: depreciation (unless the asset is land); financing costs (or reduced investment income); and possibly higher other operating and maintenance costs.

In order to operate sustainably an entity needs to be able and willing to generate higher income in future (or reduce costs elsewhere) when making decisions to increase the quantity and/or standard of its asset stock. Rating and outlay decisions should be based on striving to achieve and maintain an operating break-even or small surplus result on average over the medium/long-term. In the case of decisions regarding possible capital outlays, the focus should be the impact on the ongoing operating result (e.g. from depreciation): The quantum of the capital outlay should not be the prime concern.

\section{Long-term financial plans}

Every organisation with a significant stock of long-lived infrastructure needs a long-term financial plan. It is impossible to effectively and equitably manage service level, asset management and revenue raising decisions without this, and there really is no excuse not to have such a plan. While there are benefits from including more detail, a simple longterm financial plan can be quick and easy to prepare and is much better for decisionmaking. A long-term financial plan should show the financial impact over time (at least 5 years) from any material proposals eg regarding variations in asset stocks, service levels, operating costs and revenue. It should disclose projected financial performance against targets, and where targeted performance is forecast not to be achieved, proposals should be revised. Other considerations:

- Service levels from assets and an organisation's consequential holding of asset stocks need to be based on long-term affordability.

- Asset maintenance and rehabilitation decisions should not be based on shortterm cashflow considerations.

- Cashflow constraints should be resolved through a long-term financial plan.

- Asset management plans should be based on maintaining an organisation's preferred, long-term affordable service levels and minimising the whole of economic life costs of assets. 


\section{Conclusion}

The IPWEA Australian Infrastructure Financial Management Guidelines (2009) provide direction for all organisations and individuals with responsibility for the management of infrastructure assets, including how to:

- determine affordable service levels

- set and manage to appropriate accrual accounting based financial targets

- responsibly use debt

- maintain a soundly based long-term financial plan.

Further details on the guidelines are available from www.ipwea.org.au/AIFMG.

\section{References}

ACLG 2008, Prime Minister's Address, 18 November 2008, Australian Council of Local Government, Canberra.

ACLG 2009, Information Paper - Asset Management and Financial Planning, Australian Council of Local Government, Canberra.

IPWEA 2009, Australian Infrastructure Financial Management Guidelines, Institute of Public Works Engineering Australia, Sydney, accessed 26 November 2009, $<$ www.ipwea.org.au/AIFMG $>$.

LGPMC 2007, Framework 1 Criteria for Assessing Financial Sustainability, Local Government Financial Sustainability National Consistent Frameworks, Local Government and Planning Minister's Council, Canberra.

LGPMC 2009, Framework 2 Asset Planning and Management, Local Government Financial Sustainability National Consistent Frameworks, Local Government and Planning Minister's Council, Canberra.

LGPMC 2009, Framework 3 Financial Planning and Reporting, Local Government Financial Sustainability National Consistent Frameworks, Local Government and Planning Minister's Council, Canberra.

PriceWaterhouseCoopers 2006, National Financial Sustainability of Local Government, for Australian Local Government Association of Australia, Canberra. 


\section{Appendix 1: Authors of the Guidelines}

John Howard is an Engineer and Economist and was the Project Manager and Principal Author of the guidelines. He began his asset management journey as a municipal engineer working with the council's asset management corporate team to develop the data, business processes and systems into an asset management system integrated within the council's corporate information system. This included a single asset register, works costing system linked to individual assets, daily costing, annual revaluations with asset records linked to the geographic information system. John was the inaugural chair of the IPWEA National Asset Management Committee who developed the National Asset Management Manual in 1994. He has a keen interest in the common functions of technical and accounting systems and was one of the Tasmanian representatives on the National AAS27 Implementation Committee for 5 years. John is the Project Manager for IPWEA National Asset Management Strategy committee NAMS.AU.

Jim Dixon authored the accounting and auditing sections of the guidelines. Jim's qualifications include MBA, B Commerce and B Education. He has held the position of Assistant AuditorGeneral with the Victorian Auditor-General's Office where he was responsible for training and advising staff on the implementation of Australian equivalents to International Financial Reporting Standards (AIFRS) Prior to this, Jim provided advice and training across a wide range of private sector businesses while holding the positions of Technical Director of CPA Australia, Technical Director of chartered accountants, Pitcher Partners and as Senior Manager Research for the National Australia Bank.

John Comrie is an Economist and an Accountant. His qualifications include B. Economics, Grad. Dip. Business Administration and is a Fellow of CPA Australia. John held the positions of Executive Director of the SA Government's Office of Local Government and Local Government Association of SA and City Manager and Councillor of large metropolitan Adelaide councils. John was responsible for development of many of the legislative reforms in these fields now applicable to the SA local government sector and has often spoken on these subjects at SA and national forums. John authored the financial planning section and provided an overall review of the Guidelines. 